\title{
Employee Engagement Strategies Antecedents and Migration Intention of Medical Practitioners in Nigeria: A Theoretical Assessment
}

\author{
Ojebola Oluwatunmise , Adeniji Anthonia Adenike, Osibanjo Omotayo Adewale \\ Falola Hezekiah Olubusayo, Salau Odunayo Paul And Adeoye Funmilade Loveth \\ Department of Business Management, Covenant University, \\ Canaan Land, Ota, NIGERIA
}

Correspondence should be addressed to: Ojebola Oluwatunmise;

oluwatunmise.ojebola@stu.cu.edu.ng

Received date:14 January 2020; Accepted date:14 July 2020; Published date: 24 August 2020

Academic Editor: Chijioke Nwachukwu

Copyright (C) 2020. Ojebola Oluwatunmise, Adeniji Anthonia Adenike, Osibanjo Omotayo Adewale Falola Hezekiah Olubusayo, Salau Odunayo Paul And Adeoye Funmilade Loveth. Distributed under Creative Commons Attribution 4.0 International CC-BY 4.0

\begin{abstract}
Medical practitioners' migration to other countries of the world has a considerable effect on the appropriate health care delivery of the affected countries. Funding, training, work overload, capacity building is some of the contemporary issues confronting Nigeria health sector. All these have contributed to migration intention of many Nigerian health professionals to the developed nations. The shortage of medical doctors, nurses and midwives in Nigeria has become worrisome. This study extensively explores the antecedents of employee engagement strategies on migration intention of medical professionals in Nigeria health sector. The review centres on relevant articles from reputable and reliable databases on the subject of employee engagement and migration intention of the medical personnel. It was discovered that the antecedents of medical personnel engagement strategies could be explored to enhance medical professionals' retention in Nigeria for better health care delivery. The study offers a model that can be empirically investigated to determine the extent to which the antecedents of employee engagement influences migration intention of health workers in Nigeria.
\end{abstract}

Keywords: Employee Engagement, Behavioral Dispositions, Migration, Health Care Delivery

Cite this Article as: Ojebola Oluwatunmise , Adeniji Anthonia Adenike, Osibanjo Omotayo Adewale Falola Hezekiah Olubusayo, Salau Odunayo Paul And Adeoye Funmilade Loveth (2020), "Employee Engagement Strategies Antecedents and Migration Intention of Medical Practitioners in Nigeria: A Theoretical Assessment ", Journal of African Research in Business \& Technology, Vol. 2020 (2020), Article ID 199942, DOI: $10.5171 / 2020.199942$ 


\section{Introduction}

The health sector in Nigeria has been characterised by instability, unproductivity and inadequate workforce (Court, Emmanuel, Ann and Nwadukwe, 2018; Oleribe, Udofia, Oladipo, Ishola and Robinson, 2018). The high dearth of health workers in Nigeria is occasioned as a result of poor remuneration, delay promotion, poor working environment, job-related stress and insecurity (Butawa, Asule, Omole, Yere, Dogo and Gyuro, 2013). For instance, Vanguard (2019) assert that the inadequacy of health workers in Nigeria is so alarming as one doctor is to a population of 5000 Nigerians which is against one doctor to 600 people as suggested by World Health Organisation (WHO).

In a related perspective, Uneke, Ogbonna, Ezeoha, Oyibo, Onwe, and Ngwu (2007) observed that Nigeria's health sector is in a deplorable condition due to dearth of trained medical workers. Moreso, Nigeria according to Uneke et al. (2007) is known to be one of the foremost health-worker exporting nation in Africa due to insufficient health amenities and pitiable compensation packages which makes a sizeable number of healthcare workers migrate to advanced nations in search of sustaining and worthwhile jobs. Adebayo, Labiran, Emerenini and Omoruyi (2016) assert that the consequences of inadequate health workforce cannot be overemphasised as it would negatively impact the health status in the society in terms of ineffectual tackling of infectious endemics, the emergence of noncommunicable diseases (NCDs), increase maternal mortality and non-achievement of Millennium Development Goals (MDGs). In addition, Adebayo et al., (2016) assert that out of forty-nine nations identified by WHO to be having insufficient healthcare workers, Nigeria is in the sixth position. This challenge of the dearth of health workers might also contribute to the present high infant mortality rate in Nigeria (Adetoro and Amoo, 2014). It is opined that the strength of any country is dependent to a reasonable degree on its efficiency, which is contingent on the welfare of the population (Misua, Al-Sadat and Gerel, 2010). This implies that the well-being of the citizens of a nation is a sine qua non to productivity.
On a broader perspective, the Nigerian public sector is bedevilled with low productivity because of socio-economic management and technological factors (Oshilim and Akpesiri, 2015). However, for this study, emphasis will be on the management factor as scholars believe that the failure or success of any organisation hinges to a large extent on the management (Alkhazali and Halim, 2015; Henntschel, Muehlheusser and Sliwka, 2014). Several authors on Nigeria health sector have explored how the sector can be revived through the economic, sociological and technological approach, but limited research has been done on the management approach specifically through the engagement of the health workforce (Osain, 2011; Eme, 2014; Omoleke and Taleat, 2017; Eme, Uche \& Uche, 2014).

To this end, the importance of this research work emancipates from its objectives which are to:

a) identify the factors responsible for the high rate of Nigeria health worker's migration intention to other countries

b) explore the influence of employee engagement on Nigeria health workers' migration intention

c) ascertain the precursors of employee engagement and its strategies

d) Access the theoretical underpinnings of employee engagement and the managerial, strategic approach to curb health workers' migration.

\section{Literature Review}

\section{Workers' Migration}

Migration of health workers is the movement of health workers from inadequate income level countries to higher income level countries (Adeloye, David, Olaogun, Auta, Adesokan, Gadanya, Opele, Owagbemi, and Iseolorunkanmi, 2017; Misua et al.,2010; Ogbuabor et al.; 2016; Adeloye et al.; 2017).

\section{Causes of Nigeria Health Workers' Migration}

According to Misua, et al., (2010), migration of health workforce also referred to as brain

Ojebola Oluwatunmise, Adeniji Anthonia Adenike, Osibanjo Omotayo Adewale Falola Hezekiah Olubusayo, Salau Odunayo Paul And Adeoye Funmilade Loveth (2020), Journal of African Research in Business \& Technology, DOI: 10.5171/2020.199942 
drain is the movement of the health workers in quest of an improved standard of living and life value, better earnings, access to innovative know-how and the more secured socio-economic environment globally. The rate at which Nigeria health workers migrate to other countries, which is an aspect of global mobility, is so alarming as over 35,000 doctors out of the 72,000 registered are practising abroad (Vanguard, 2017). The movement of Nigeria health workers to other countries is occasioned by several factors which are hindering efficient healthcare delivery. It has been observed that the inadequacy of human resources in Nigeria health sector is significantly responsible for the indigent population health in the country (Salami, Dada and Adelakun, 2016; International Organisation for Migration, 2014).

WHO (2014) observed that the movement of health workers around the world is motivated by migrants seeking better working conditions in other countries. The decision of health workers' migration is based on personal circumstances coupled with economic and social situations as well as state interventions. (Stilwell, Diallo, Zurn, Vujicic, Adams and Poz, 2004). Economic issues in this context underscore good wages and working conditions; social context emphasises aspects like social unrest and deprivations while state interventions like the placement of international vacancies, flexible issuance of visas and work permits to intending migrants have a significant influence on health workers' intention to migrate (Stilwell et al., 2004).

In addition, Medic West Africa (2019) posits that a good number of the health workforce are faced with several backlogs of salaries, pitiable welfare, inadequate health facilities and work overload. Moreso, the main factors responsible for human resources inadequacy in Nigeria according to Eriki, Oyo-Ita, Odebo, Udoh, Omaswa and Kadama, (2015) include inadequate personnel planning and management practices, long working hours, unsafe workplaces, inadequate compensation, and limited access to professional development opportunities. Also, Uneka et al. (2007) posit that Nigeria Health workers earn meagre salaries, work in unsafe areas, have substantial workloads and lack the most basic health facilities to work and low prospect for career advancement. Nevertheless, Bello, Ajayi and Asuzu (2015) observed that organisational factors like authoritarian leadership style, lack of goal and role clarity as well as poor remuneration constitute push factors that motivate health workers migrate to developed nations. It is also being observed that health workers experience low pay, irregular promotion, abusive supervision, unfriendly job attributes and stress on the job which influence their intention to migrate (Ogbuabor, Okoronkwo, Uzochukwu and Onwujekwe, 2016).

\section{Influence of Employee Engagement on Migration Intention}

Ibidunni, Osibanjo, Adeniji, Salau and Falola (2016) assert that continuous success of any organisation is dependent on the employees' contribution and commitment which can be fostered through employee engagement. The importance of employee engagement cannot be over emphasised as organisational success depends on employee's productivity which is fostered through employee's commitment and involvement towards his/her organisation (Pratima and Bhagirathi, 2016). Employee engagement is an inevitable managerial tool that management uses to foster productivity, performance and retention as engagement ensures an exploratory state that enables organisation members to involve deeply on their individual selves in role performances (Falola, Salau, Olokundun, Oyafunnke-Omoniyi, and Ibidunni, 2018; Lailah, Christo, and Christoff, 2014).

Organisations today have come to realise that not all personnel are devoted and productive but engaged workers, who are mentally and emotionally attached to the organisation, are obligated to achieve its goals and dedicated towards its values like going extra mile beyond their basic job responsibility (Bhavani, Sharavan and Arpitha, 2015). Falola, Oludayo, Igbinoba, Salau and Borishade (2018) opine that engagement entails passion and the disposition of an employee to invest his own

Ojebola Oluwatunmise , Adeniji Anthonia Adenike, Osibanjo Omotayo Adewale Falola Hezekiah Olubusayo, Salau Odunayo Paul And Adeoye Funmilade Loveth (2020), Journal of African Research in Business \& Technology, DOI: 10.5171/2020.199942 
self and extend his extra effort to assist his organisation accomplish its goals, which is beyond ordinary satisfaction with the employment contract. Thus, employee engagement is the level of commitment and participation a worker invests towards their organisation and its success (Syed, Hussain, Abdul, Zamir and Ali, 2019, Falola, Adeniji, Adeyeye, Igbinnoba, and Atolagbe, (2020). The survival of an organisation is dependent on how leaders of the firm work hard to engage workers because the sustainability of any organisation is dependent on its workforce (Schrita and Mohamad, 2017, Falola, Adeniji, Adeyeye, Igbinnoba \& Atolagbe, 2020).

Engaging employees is now an emerging organisational concept, and it has been recognised as one of the significant primacies of human resource administrators in any work environment (Bhatla, 2011). The term employee engagement refers to the level of loyalty and engrossment of the employees to achieve organisational goals. Shuck and Reio (2014) further viewed employee engagement as a holistic motivational theory reflecting the concurrent investment of an individual's behavioural, rational, and emotive energy in productive performance. Thakur (2014) further emphasised the advantage of organisations engaging their employees as it can significantly affect worker retention, efficiency, and dependability as well as positively impact organisation repute and overall stakeholder assessment.

According to Nada and Singh (2016), employee engagement is defined as an employee's sagacity of persistence and intensive vigour that involves the display of personal ingenuity, flexibility, energy, and diligence directed toward the realisation of the organisation's goals. More so, employee engagement can be described as a discrete and distinctive concept that involves intellectual, emotive, and behavioural components related to individual role performance (Marcus and Namitha, 2017). Passanan, Waiphot, Kwanta, Thaywuse and Patipol (2018) also referred to employee engagement as the extra resources like time, brainpower, and energy employees invest in their work that result in discretionary effort. Shuck and Reio (2014) further term employee engagement as the mental, passionate, and developmental energy an employee display toward positive organisational outcomes. Besides, Wang and Tseng (2019) posit employee engagement as the psychosomatic state where workers have a vested concern in the organisation's by going above the written task /job requirements. Nevertheless, Deepika and Sampurna (2018) added that employee engagement is the substantial degree of the passionate and logical link that an employee has for his/her work, organisation, colleagues and superiors which empowers him/her to put in additional extra effort to his/her work. Other known benefits of employee engagement according to Falola, et al. (2018) include low workforce turnover, enhanced employee productivity, improved support of the organisation, positive influences on health and welfare, increased self-efficiency and receptiveness to innovative dynamism.

It is imperative for hospitals management and administrators to know how to drive employees towards being engaged in their work. It has been observed that health managers are deficient in the motivation and management of health workers (Adeloye et al., 2017). This suggests that hospitals' or health facilities' managers should go for human resources management training. How can health workers be engaged and committed? How can they be retained in the health sector? How can they be motivated to go the extra mile beyond their employer expectations? These questions, if addressed, can mitigate the challenge of Nigeria health workers' migration to other countries.

\section{Drivers and Strategies of Employee Engagement}

Omer, Qaisar, Talat, Khalil and Aamer (2011) assert that when managers appropriately utilise employee engagement strategies like profession prospects, organisational support, investment on employees, employees' involvement in decision making, recognition and reward, fair treatment and equality and transformational leadership style, employees will be enthused to their

Ojebola Oluwatunmise , Adeniji Anthonia Adenike, Osibanjo Omotayo Adewale Falola Hezekiah Olubusayo, Salau Odunayo Paul And Adeoye Funmilade Loveth (2020), Journal of African Research in Business \& Technology, DOI: 10.5171/2020.199942 
organisation. Dorothea (2013) also posits that employee engagement motivations are driven both financially and non-financially as workers are not inspired by money alone as corroborated by Safaa (2018) that employees can be motivated to be engaged intrinsically and extrinsically.

\section{Organization Reputation}

Nigeria health sector is currently challenged with issues that are detrimental to the sector image before its stakeholders (Adeloye et al., 2017). Extant studies on employee engagement and corporate reputation show that both constructs are cyclically linked as one can potentially influence the other. Employee behaviour can drive corporate reputation according to (Friedman, 2009; Helm, 2011), and also corporate reputation influences how employees behave and perform as posited by (Davies, Chun, Da Silva, and Roper, 2004; and Helm, 2011). However, in this context, we are concerned with how organisation reputation can motivate employee engagement.

One of the leading researchers on company reputation, Fombrun (1996), defined it as a constant depiction of an organisation's previous activities and prospects that describe the firm's whole appeal to all of its main stakeholders when compared with other organisations. This implies that reputation is a replication or an appraisal observed by stakeholders, including their employees in the past. Men (2012) also described corporate reputation as the totality of an organisation stakeholder's perception of how sensitive organisational activities are satisfying the demand and hopes of many organisational stakeholders. In a related context, Gotsi and Wilson (2001) succinctly define organisation reputation as a stakeholder's overall valuation of an organisation over time, and this assessment is based on the stakeholder's personal experiences with the organisation, their means of communication that gives information about the organisation actions and evaluation with the activities of other organisations. This definition suggests that when an employee perceives that his organisation is better compared to other competitors, he tends to be engaged.

\section{Job Designing}

Job design, according to Beliasi and Sklikas (2013), is the means of organising task and duties into an organisational division of work. Does job design always start with a breakdown of task requirements like what should be done? What are the motivating characteristics such as independence, responsibility, freedom of choice and selfcontrol? Garg and Rastogi (2006) observe that well-designed jobs can have a positive influence on employee satisfaction and employee productivity as a well-designed task will foster motivation, fulfilment and performance of the employees. Osibanjo, Salau, Falola and Oyewunmi (2016) also affirm that it is imperative to design jobs to minimise and foster satisfaction of employees because a job that is not adequately designed can trigger stress. One of the identified factors pushing Nigeria health workers to migrate according to (Ogbuabor et al, 2016) is stress. Thus, health regulators and administrators can use job design as a mitigating strategy to minimise stress.

\section{Career Development Opportunities}

According to Mutunga (2009), employees' career advancement is the process which is formal, organised and planned effort to accomplish the balance between the requirement of the organisation's workforce and individual career desires. When management provides sufficient prospect for training and support regarding career development, they help foster employee advancement and motivate employees to be engaged. Career advancement opportunities, according to Hughes and Rog (2008), is the degree to which workers have the prospects for career growth and advancement. This implies that the more workers are satisfied with their opportunity for career advancement, the more they are willing to be engaged. Mone and London (2010) also observe that employees will feel more involved if organisations provide a motivating job with prospects for career growth. According to Mutunga (2009),

Ojebola Oluwatunmise, Adeniji Anthonia Adenike, Osibanjo Omotayo Adewale Falola Hezekiah Olubusayo, Salau Odunayo Paul And Adeoye Funmilade Loveth (2020), Journal of African Research in Business \& Technology, DOI: 10.5171/2020.199942 
when an organisation ensures that the job given to the employees complements with their career goals, it provides effective employee engagement and retention. This is also corroborated by Vazirani (2007) that career growth influences engagement and retention of workers. Organisations with high levels of engagement provide employees with opportunities to develop their abilities, learn new skills, acquire new knowledge and realise their potential.

\section{Investment on Employees}

Perceived investment in employee development according to Omer, Qaisar, Talat, Khalil and Aamer (2011) refers to employees' valuation of their organisations' effort to help them learn to recognise and get new skills and proficiencies that will allow them attain new and challenging positions. Erasmus, Loedolff, Mda, and Nel (2011) further posit that when organisations train their workers, they are modifying their skill, knowledge and behaviour in other to increase their productivity and ability to accomplish organisational aims and objectives. The tangible work experiences acquired during this process build employees' capacity which significantly impacts productivity and fosters commitment (Kai, Altman, and Roussel, 2008).

As a result, employees are indebted to show gratefulness for the organisation's investment in their growth, indicating that they do earn value from the process which will make them more motivated, committed and loyal (Alexandros and Bouris, 2008). This means that the organisation appreciates employees' contributions, care about their relevance, and as a result, they return to the organisation in positive ways by exhibiting positive behavioural dispositions that proportionate with the extent they feel the organisation has invested in them (Omer et al., 2011).

\section{Work Environment}

One of the core elements in the notion of employee engagement is the strong affective commitment of engaged workers and high involvement in their work. Employee involvement ensures a high degree of affection to the organisation, which brings about connectivity and subsequently, engagement (Lailah, Christo and Christoff, 2014). Also, Chitra and Munivenkatappa (2017) assert that giving adequate opportunities for development and advancement to employees and ensuring that they have everything they need to do their jobs including physical or material and information resources foster employee engagement. In another context, Chandrasekhar (2011) asserts that most workers spend a substantial amount of their time within the internal environment which impacts their mental and emotional states, focus, behaviour, abilities and performance at work. In essence, the nature and value of the physical work environment are assumed to influence how workers interact, execute their roles as well as their mental, physical and emotional states (Oyetunji, 2014; Falola, Oludayo, Igbinoba, Salau, \& Borishade, 2018).

\section{Compensation}

Bibi, et al (2017) opine that employees are the most valuable asset of an organisation and retaining these employees is inevitable for the success of the organisations. Compensation packages entail salaries, bonuses and incentives, and these have a significant impact on employee satisfaction (Chiekezie, Emejulu and Nwanneka, 2017). According to Ldama and Peter (2017), compensation refers to monetary benefits that accrue to workers both intrinsically and extrinsically like health care, vacation and leave grant, total salary package and other financial benefits. Extant literature on Nigeria health workers' migration to other countries emphasised inadequate compensation as the significant factor for migration (Misua et al.,2010; Ogbuabor et al.;2016; Adeloye et al.; 2017). According to Bibi et al. (2017), compensation is regarded to be one of the core essentials in workers' retention. Though it is expensive to retain experienced and skilled employees, it is more costly to let them leave because failure to maintain them has severe financial implications on the organisation like recruitment and training cost including the extended period to acclimatise (Ldama and Peter, 2017).

Ojebola Oluwatunmise, Adeniji Anthonia Adenike, Osibanjo Omotayo Adewale Falola Hezekiah Olubusayo, Salau Odunayo Paul And Adeoye Funmilade Loveth (2020), Journal of African Research in Business \& Technology, DOI: 10.5171/2020.199942 
Nevertheless, nonfinancial rewards such as recognition and other inherent rewards are unavoidable for job satisfaction which can also lead to a high level of employee engagement and satisfaction and retention (Tessema, Kathryn and Abel, 2013). Leadership which is the capability to influence and inspire the actions of subordinates in an inspiring and motivating manner which fosters the achievement of objectives of both the team and the organisation is also intrinsically motivated (Alexandra and Maria, 2015). Alexandra and Maria (2015) further opine that leadership must be able to drive workers' engagement by giving primacy to the personal needs of their subordinates and inspire them to put the collective interests first over the individual attention as a means to accomplish the organisational goals.

This is because one of the main characteristics of effective leadership is the ability to increase the level of subordinate motivation in exhibiting good behavioural dispositions (Alexandra and Maria, 2015). These behaviours, when exhibited, highlight the principle of reciprocity which influence the subordinates to engage in the process of social exchange with their leaders. This implies that leadership style of the organisation like transformational leadership can motivate workers to be loyal to the organisation as a way to return the favourable treatment received from their leaders (Boerner, Eisenbeiss, and Griesser, 2007). Thus, subordinates under a transformation leader will be motivated to reciprocate because of the motivation and self-esteem they might have received from their superiors.

\section{Theoretical Underpinnings of Employee Engagement and the Managerial Strategic Approach}

A theory is a form of a notion that explicitly explains a particular concept or phenomenon. Some theories have been developed to provide understanding into what employee engagement is all about. For instance, social exchange theory is among the most influential theoretical models for understanding good employees' behavioural dispositions which entails a series of interactions that generate obligations (Cropanzano and Mitchell, 2005). Social exchange contextually is a process of social interaction by showing how someone's (employer) behaviour reinforced the other's behaviour (employee) and vice versa. Cook and Rice (2003) succinctly describe it as a process that involves the norm that when a party does another a favour, there is a general expectation of some future return and its exact nature is not stipulated in advance. For instance, this implies that when a party like an employer does a favour to the employee, such worker will also reciprocate in positive return and vice versa. It is expected for employees who receive an adequate or satisfactory level of most of all, the precursors identified in Fig 1.1 not to reciprocate in a good return to their employers including having a negative intention to migrate.

In addition, perceived organisation support theory (OST), according to Baran, Shanock and Miller (2011), refers to the degree to which employees believe their work organisation values their contributions and cares about their well-being (In workplaces, trade effort and dedication to their organisation for such tangible incentives as pay and fringe benefits and such socioemotional benefits as recognition and investment in them (Baran, Shanock and Miller, 2011).

In this $21^{\text {st }}$ century, Eisenberger, Malone and Presson (2016) opine that it is important for organisations to acknowledge their employees as valuable sources of human capital. This is because the employees' perception that the organisation values their contributions and as well cares about their well-being will have significant benefits for both parties. As observed by Colakoglu, Culha and Atay (2010), one of the most important predictors of organisational commitment is job satisfaction which has a positive effect on the dimensions of organisational commitment. If workers perceived organisational support to be positive, they tend to be satisfied with the job. This is further corroborated by Colakoglu et al. (2010) that one of the most important predictors of job satisfaction is organisational support.

Ojebola Oluwatunmise, Adeniji Anthonia Adenike, Osibanjo Omotayo Adewale Falola Hezekiah Olubusayo, Salau Odunayo Paul And Adeoye Funmilade Loveth (2020), Journal of African Research in Business \& Technology, DOI: 10.5171/2020.199942 


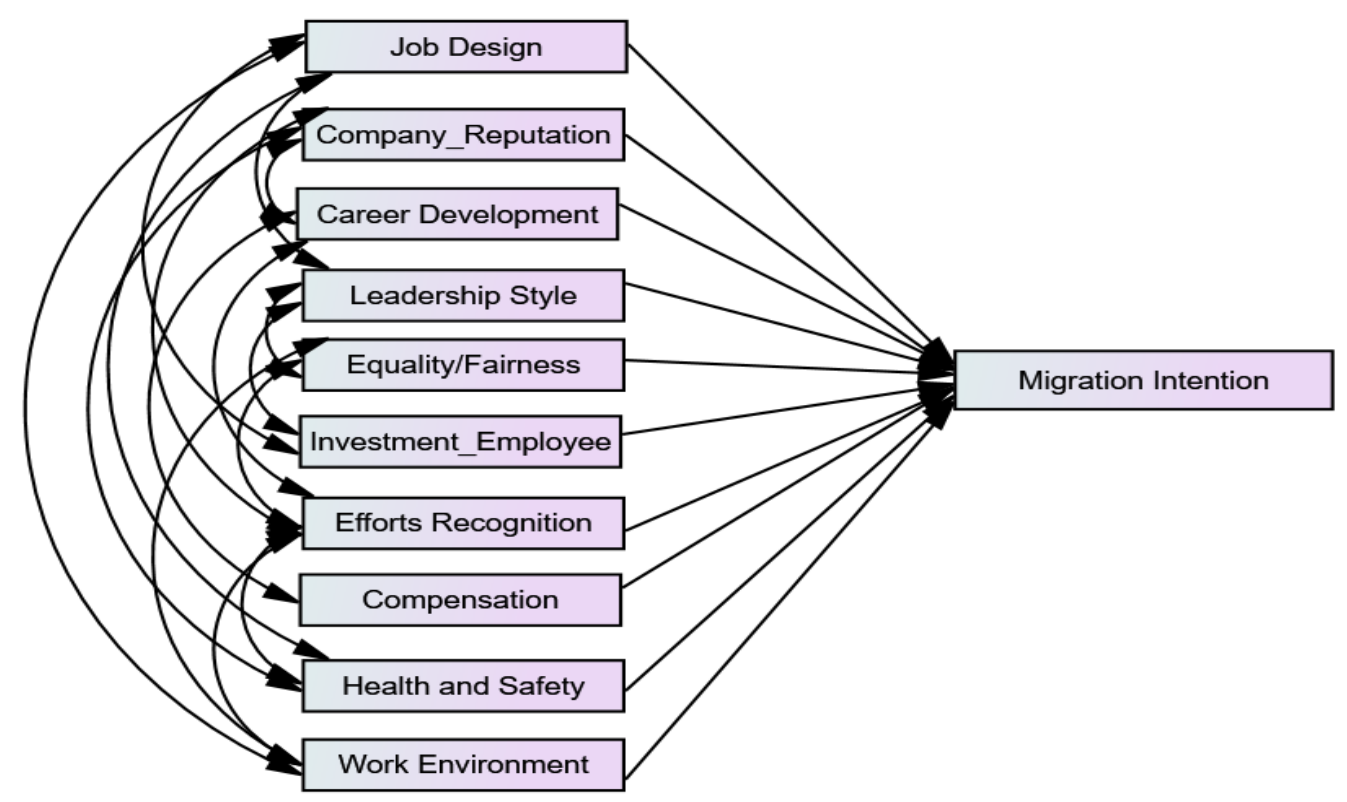

Fig. 1: Proposed employee engagement Strategies and Retention Model

As depicted in Figure 1, it is observable that some precursors of employee engagement as identified are what health managers should do to motivate health workers' satisfaction. Extant literature on the challenge of health workers' migration in Nigeria identified inadequate poor human resources planning and management practices. Healthcare administrators and managers, both at the private and public sector, focus more on motivating their workers to be committed. Policymakers and managers must imbibe $21^{\text {st-century human }}$ resources management practices to health administration. Also, measures to retain health workers encourage the return of migrated ones, and to ensure their integration upon arrival is inevitable for adequate healthcare delivery in Nigeria. It is, therefore, inevitable to empirically investigate the proposed model in Figure 1.1.

\section{Acknowledgement}

The authors wish to acknowledge Covenant University Centre for Research, Innovation and Discovery (CUCRID) for providing support in carrying out this research.

\section{References}

- $\quad$ Adebayo, O., Labiran, A., Emerenini, C and Omoruyi, L. (2016) "Health workforce for 2016-2030: Will Nigeria have enough?", International Journal of Innovative Healthcare Research, 4(1): 9-16

- Adeloye, D., David, R., Olaogun, A., Auta, A., Adesokan, A, Gadanya, M., Opele, J., Owagbemi, 0 and Iseolorunkanmi, A (2017) "Health workforce and governance: the crisis in Nigeria", Human Resources for Health, 15(32), 1-8

- Adetoro, G and Amoo, E. (2014) "A statistical analysis of child mortality: Evidence from Nigeria", Journal of Demography and Social Statistics, Maiden Edition, 110-120.

- Alexandros, S. and Bouris, J. (2008) "Employee perceived training effectiveness relationship to employee attitudes", Journal of European Industrial Training, 32 (1), 63-76

- $\quad$ Alexandra, R. and Maria, F. (2015) "The impact of transactional and transformational leadership style on

Ojebola Oluwatunmise, Adeniji Anthonia Adenike, Osibanjo Omotayo Adewale Falola Hezekiah Olubusayo, Salau Odunayo Paul And Adeoye Funmilade Loveth (2020), Journal of African Research in Business \& Technology, DOI: 10.5171/2020.199942 
organisational citizenship behaviours". Psico-USF, Bragança Paulista, 20 (3), 493-504.

- Alkhazali, Z and Halim, M. (2015) "The influence of strategic human resource management on firm performance of Jordan's corporate organisations", International Journal of Academic Research in Business and Social Sciences, 5, (12), 342-353

- Baran, B., Shanock, L and Miller, L (2011) "Advancing organisational support theory into the twenty-firstcentury world of work", Journal of Bus Psychology, DOI 10.1007/s10869011-9236-3.

- Beliasi, D and Sklikas, D (2013) "Aspects of job design", International Journal of Human Resource Management and Research, 3 (4), 8594

- Bhatla, N. (2011) "To study the employee engagement practices and its effect on employee performance with special reference to ICICI and HDFC Bank in Lucknow", International Journal of Scientific and Engineering Research, 2 (8), 1-7

- Bhavani, A., Sharavan and Arpitha. (2015) "A study of the effectiveness of employee engagement in automobile industry", International Journal of Economics and Management Sciences 4 (10), 1-5.

- $\quad$ Bello, S, Ajayi, T and Asuzu, C. (2015) "Determinants of Job Satisfaction among Physicians in Public Hospitals in Calabar, Nigeria", Journal of Community Medicine and Primary Health Care, 30 (1) 19-33.

- Bibi, P., Pangil, F., Johari, J and Ahmad, A. (2017) "The impact of compensation and promotional opportunities on employee retention in academic institutions: The moderating role of the work environment", International Journal of Economic Perspectives, 11 (1), 378391.

- Boerner, S., Eisenbeiss, S., and Griesser, D. (2007) "Follower behaviour and organisational performance: The impact of transformational leaders", Journal of
Leadership and Organisational Studies, 13 (15), 15-26.

- $\quad$ Butawa, N., Sule, G., Omole, N., Yere, K and Gyuro, J (2013) "Assessment of job satisfaction among health workers in a tertiary hospital in Zaria, Northern Nigeria", Savannah Journal of Medical Research and Practice, 2 (2), 54-62.

- Chandrasekar, K. (2011) "Workplace environment and its impact on organisational performance in the public sector", International Journal of Enterprise Computing and Business Systems, http://www.ijecbs.com/January201 1/N4Jan2011.pdf

- Chiekezie, O. M., Emejulu, G., \& Nwanneka, A. (2017) “Compensation management and employee retention of selected commercial banks in Anambra State, Nigeria". Archives of Business Research, 5(3), 115-127.

- Chitra, N. and Manivenkatappa (2017) "An empirical study on employee engagement and its effect on demographic variables in electronic industries in India", International Journal of Academic Research and Development, 2(4), 6673.

- Colakoglu, U., Culha, O and Atay, H (2010) "The effects of perceived organisational support on employees' affective outcomes: evidence from the hotel industry", Tourism and Hospitality Management, 16 (2), 125150.

- Cook, K and Rice, E (2003) Social Exchange Theory, Handbook of Social Psychology, Kluwer Academic/Plenum Publishers, New York, 2003.

- Court, T; and Emmanuel, A; Ann, O and Nwadukwe, U. (2018)" Organisational justice and turnover intention among medical and nonmedical workers in university teaching hospitals", Mediterranean Journal of Social Sciences, 9 (2), 149160.

- Cropanzano, R and Mitchell, M (2005) "Social exchange theory: An interdisciplinary review", Journal of Management, 31 (6), 874-900

Ojebola Oluwatunmise, Adeniji Anthonia Adenike, Osibanjo Omotayo Adewale Falola Hezekiah Olubusayo, Salau Odunayo Paul And Adeoye Funmilade Loveth (2020), Journal of African Research in Business \& Technology, DOI: 10.5171/2020.199942 
- $\quad$ Davies, G., Chun, R., Da Silva, R. V., and Roper, S. (2004) “A corporate character scale to assess employee and customer views of organisation reputation", Corporate Reputation Review, 7, 125-146.

- $\quad$ Deepika, P and Sampurna, R. (2018) "Talent management and employee engagement- a meta-analysis of their impact on talent retention", Industrial and Commercial Training, (50), 4, 185-199.

- Dorothea, W. (2013) "The Relationship between employee engagement, organisational citizenship behaviour and counterproductive work behaviour". International Journal of Business Administration. 4(10.), 54-30.

- Eisenberger, R., Malone, G and Presson, W (2016) Optimising perceived organisational support to enhance employee engagement, Society for Human Resource Management and Society for Industrial and Organizational Psychology, University of Houston

- Eme, O. (2014) "Building a Solid Health Care System in Nigeria: Challenges and Prospects", Academic Journal of Interdisciplinary Studies. 10.5901.

- $\quad$ Eme, I, Uche, A and Uche, B (2014) "Building a Solid Health Care System in Nigeria: Challenges and Prospects", Academic Journal of Interdisciplinary Studies, 3 (6), 501-510.

- $\quad$ Erasmus, B., Loedolff, P., Mda, T, and Nel, P. (2009) Managing training and development in South Africa, Oxford.

- $\quad$ Eriki, P., Oyo-Ita, A., Odebo, R., Udoh, A., Omaswa, F and Kadama, P (2015) Workforce in Nigeria-Stock and flow of medical and dental practitioners in Nigeria, with particular focus on health workforce training in Cross River state, African Centre for Global Health and Social Transformation.

- Falola, H.O., Adeniji, A.A., Adeyeye, J.O., Igbinnoba, E.E., Atolagbe, T.O. (2020) "Measuring institutional support strategies and faculty job effectiveness". Heliyon 6(3):e03461.

- Falola, H., Oludayo, O., Igbinoba, E., Salau, 0, and Borishade, T. (2018)
"Measuring work engagement strategies and employees' behavioural outcomes in Nigerian Universities", Journal of Business and Retail Management Research, 13 (2), 98-107.

- Falola, H.O, Salau, O.P, Olokundun, A.M. Oyafunnke-Omoniyi, C.O and Ibidunni, A.S. (2018) 'Employees' intrapreneurial engagement initiatives and its influence on organisational survival", Business: Theory and Practice, 19(9), 9-16.

- Fombrun, C. J., and Van Reel, C. (1997) "The reputational landscape", Corporate Reputation Review, 1, 514.

- Friedman, B. A. (2009) "Human resource management: Role implications for corporate reputation", Corporate Reputation Review, 12, 229-244.

- Garg, P and Rastogi, R, (2006) "New model of job design: motivating employees' performance", Journal of Management Development, 25 (6), 572-587

- Gotsi, M. and Wilson, A. (2001) "Corporate reputation: Seeking a definition, Corporate

Communications" An International Journal, 6 (1), 24-30.

- Helm, S. (2011) "Employees' awareness of their impact on corporate reputation". Journal of Business Research, 64, 657-663.

- Hentschel, S; Muehlheusser, G and Sliwka, D. (2014) The contribution of managers to organisational success: Evidence from German soccer, Discussion Paper No. 8560, Retrievedhttp://ftp.iza.org/dp8560.pdf

- Hughes, C and Rog, E. (2008) "Talent management: A strategy for improving employee recruitment, retention and engagement within hospitality organisations", International Journal of Contemporary Hospitality Management. 20. 743-757.

- Ibidunni, S., Osibanjo, O., Adeniji, A., Salau, 0 and Falola, H. (2016) "Talent retention and organisational performance: A competitive

Ojebola Oluwatunmise , Adeniji Anthonia Adenike, Osibanjo Omotayo Adewale Falola Hezekiah Olubusayo, Salau Odunayo Paul And Adeoye Funmilade Loveth (2020), Journal of African Research in Business \& Technology, DOI: 10.5171/2020.199942 
positioning in the Nigerian banking sector", Periodica Polytechnica Social and Management Sciences, 24(1), 113.

- International Organisation for Migration, (2014) Mapping of Nigeria health and education professionals in the United States of America, Retrieved- iom.int/books/mappingNigerian-health-and-educationprofessionals-united-states-america

- Kai, M., Altman, Y, and Roussel, J. (2008) "Employees training needs and perceived value of training in the pearl river of China: A human capital development approach", Journal of European Industrial Training, 32 (1), 19-31,

- Lailah, I., Christo, B and Christoff, B. (2014) "A model to measure employee engagement", Problems and Perspectives in Management, 12 (4), 520-532.

- Ldama, J and Peter, T (2017) "Effect of compensation/pay on staff retention in selected commercial banks in Adamawa State, Nigeria", International Journal of Scientific Research and Management, 5 (09),7033-7039

- Madu, G., Asawo, S and Gabriel, J. (2017) "Physical workplace environment and employees' engagement: a theoretical exploration", International Journal of Arts and Humanities, 1 (10), 865-884.

- Marcus, A and Namitha, G. (2017) "Impact of the demographic variables on the employee engagement" An analysis, 502- 510.

- Medic West Africa (2019) "Healthcare Market Insights: Nigeria, Retrieved- on 31st December, 2019, https://www.medicwestafrica.com/ content/dam/Informa/medic

- Men, L. (2012) "The effects of organisational leadership on strategic international communication and employee outcomes", M.I: U.S.A.: Proquest.

- Misua, Y., Al-Sadat, N and Gerel, A. (2010) "Brain-drain and health care delivery in developing countries", Journal of Public Health in Africa, 1: e6, 21-22
- Mone, E.M. and London, M., (2010) Employee engagement: Through effective performance management- A practical guide for managers.:Talyor \& Francis Group NY.

- Mutunga, C.N. (2009) Factors that Contribute to the Level of Employee Engagement in the Telecommunication Industry in Kenya: A Case Study of Zain Kenya. University of Nairobi, Nairobi.

- Nada, A and Singh, S. (2016) "Competing through employee engagement: A proposed framework", International Journal of Productivity and Performance Management 65. 831-843.

- Ogbuabor, D., Okoronkwo, I, Uzochukwu, B and Onwujekwe, 0. (2016) "Determinants of job satisfaction and retention of public sector health workers in southeast Nigeria", Int. J. Med. Health Dev, 21 (2), 27-39

- Oleribe, 0; Udofia, D; Oladipo, 0; Ishola, T and Robinson, S. (2018) 'Healthcare workers' industrial action in Nigeria: a cross-sectional survey of Nigerian physicians", Human Resources for Health, 16 (54), 1-10.

- $\quad$ Omer, M., Qaisar, A., Talat, K., Khalil, M and Aamer, W. (2011) "Perceived investment in employee development and turnover intention: A social exchange perspective", African Journal of Business Perspective, 5 (5), 1904-1914.

- Omoleke, L and Taleat, A (2017) "Contemporary issues and challenges of health sector in Nigeria", Research Journal of Health Sciences, 5 (4), 210216.

- Osain, M. (2011) “The Nigerian health care system: Need for integrating adequate medical intelligence and surveillance systems", Journal of Pharmacy \& Bio allied Sciences. 3. 470-8.

- Osibanjo, O., Salau, O., Falola, H., \& Oyewunmi, A. (2016) "Workplace stress: Implications of organisational performance in Nigeria public

Ojebola Oluwatunmise, Adeniji Anthonia Adenike, Osibanjo Omotayo Adewale Falola Hezekiah Olubusayo, Salau Odunayo Paul And Adeoye Funmilade Loveth (2020), Journal of African Research in Business \& Technology, DOI: 10.5171/2020.199942 
university", Business: Theory and Practice, 17 (3), 261-2.

- Oshilim, N and Akpesiri, O. (2015) “Governance, Employee Engagement and Improved Productivity in the Public Sector: The Nigerian Experience", Journal of Investment and Management, 4 (5), 141-151.

- Oyetunji, C. O. (2014) 'Lecturers' perceptions of open-plan office in tertiary institutions". Journal of Education and Training, 1, 28-38.

- Passanan, P., Waiphot, K., Kwanta, B., Thaywuse, B and Patipol, H. (2018) "Employee engagement: validating the ISA engagement scale", Conference of the International Journal of Arts \& Sciences, 11(01); 99108.

- $\quad$ Pratima, S and Bhagirathi, N. (2016) "Employee management and its impact on organisational success - A study in manufacturing company, India," Journal of Business and Management, 18 (4), 52-57.

- Popoola, O. (2018) "Population growth and life expectancy in Nigeria: Issues and further considerations", Humanities and Social Science Research; 1 (1); 30-38

- $\quad$ Popli, S and Rizvi, I. (2016) "Drivers of employee engagement: The role of leadership style", Global Business Review 17(4), 1-15

- Safaa, S. (2018). The impact of motivation on organisational citizenship behaviour (OCB): The mediation effect of employees' engagement, Journal of Human Resource Management, 6 (2), 58-66. doi: 10.11648/j.jhrm.20180602.13

- Salami, B., Dada, F and Adelakun, F. (2016) "Human resources for health challenges in Nigeria and nurses' migration", Policy, Politics and Nursing Practice, 17 (2), 76-84.

- Schrita, 0, and Mohamad, H. (2017) "Effective employee engagement in the workplace", International Journal of Applied Management and Technology, 16 (1), 50-67.

- Shuck, B and Reio, G. (2014) "Employee engagement and wellbeing: A moderation model and implications for practice", Journal of
Leadership \& Organizational Studies, 21(1), 43 -58.

- $\quad$ Stilwell, B., Diallo, K., Zurn, P., Vujicic, M., Marko, Adams, $\mathrm{O}$ and Poz, M (2004). Migration of health workers from developing countries, strategic approaches to its management, Bulletin of World Health Organisation, 82 (8), 595-600

- $\quad$ Syed, D., Hussain, K., Abdul, A., Zamir, $A$ and Ali, S. (2019) "Impact of employees' recognition, rewards and job stress on job performance: mediating role of perceived organisation support", Journal of Management. 10(3), 32-37.

- $\quad$ Tessema, M., Kathryn, R., and Abel, E. (2013) "The effects of employee recognition, pay, and benefits on job satisfaction: Cross country evidence", Journal of Business and Economics, 4 (1), 1-12.

- Thakur, P. (2014) "A research paper on the effect of employee engagement on job satisfaction in IT sector", Journal of Business Management and Social Sciences Research, 3 (5), 31-39.

- Uneke, C., Ogbonna, A., Ezeoha, A., Oyibo, P., Onwe, F and Ngwu, B (2007) "Innovative Health Research Group. The Nigeria health sector and human resource challenges", The Internet Journal of Health, 8 (1), 1-5

- Vanguard (2017). 35,000 doctors have left for the UK and US-report, Retrieved-

https://www.vanguard.com/2017/1 2/35-000-doctors-left-nigeria-uk-usreport/

- Vanguard (2019) Nigeria must recruit 10605 doctors annually to meet population needs, Retrievedhttps://www.vanguardngr.com/201 9/08/Nigeria-must-recruit-10605doctors-annually-to-meetpopulation-needs

- Vazirani, N. (2007) Employee Engagement SIES: College of Management Studies Working Paper Series.

- Wang, C and Tseng, K. (2019) "Effects of Selected Positive Resources on Hospitality Service Quality: The Mediating Role of Work Engagement". Sustainability,11. 2320.

Ojebola Oluwatunmise , Adeniji Anthonia Adenike, Osibanjo Omotayo Adewale Falola Hezekiah Olubusayo, Salau Odunayo Paul And Adeoye Funmilade Loveth (2020), Journal of African Research in Business \& Technology, DOI: 10.5171/2020.199942 
- World Health Organisation (2014)

Migration of health workers who code of practice and the global

economic crisis, WHO Document
Production Services, Geneva,
Switzerland.

Ojebola Oluwatunmise , Adeniji Anthonia Adenike, Osibanjo Omotayo Adewale Falola Hezekiah Olubusayo, Salau Odunayo Paul And Adeoye Funmilade Loveth (2020), Journal of African Research in Business \& Technology, DOI: 10.5171/2020.199942 